\title{
Impact of soft tissue graft on the preservation of compromised sockets: a randomized controlled clinical pilot study
}

\author{
Bruno Segnini', Fausto F. F. Borges-Filho², Lélis G.Nicoli', Marcelo Gonçalves', Cláudio \\ Marcantonio ${ }^{3}$, Guilherme J.P.L. Oliveira ${ }^{4}$, Elcio Jr. Marcantonio ${ }^{1.5}$ \\ 1. Universidade Estadual Paulista, Faculdade de Odontologia de Araraquara, Departamento de Diagnostico e Cirurgia, \\ Araraquara, Brasil. \\ 2. Faculdades Integradas Espírito-Santenses, Faculdade de Odontologia, Departamento de Clínica Odontológica, Vitó- \\ ria, Brasil. \\ 3. Universidade de Araraquara, Faculdade de Odontologia, Departamento de Implantodontia, Araraquara, Brasil \\ 4. Universidade Federal de Uberlândia, Faculdade de Odontologia, Departamento de Periodontia e Implantodontia , \\ Uberlândia, Brasil \\ 5. Faculdade Ilapeo, Faculdade de Odontologia, Departamento de Implantodontia, Curitiba, Brasil
}

\begin{abstract}
The aim of this pilot study was to evaluate the impact of the association of free gingival graft (FGG) or collagen-matrix xenograft (CMX) to deproteinized bovine bone graft (DBBG) on the preservation of post-extraction sockets with facial-wall defects. Sixteen patients who presented a maxillary tooth with a facial bone defect and indication of extraction were selected. After the surgical procedure, all the post-extraction sockets were filled with $D B B G$ and covered with a collagen membrane. The cervical part of the socket was then sealed with either FGG or CMX. Clinical and tomographic analyses were performed at baseline and 4 months after the grafting procedure. The FGG
\end{abstract}

sockets showed higher values for the width of the bone ridge than the CMX sockets at 4 months. There was no difference regarding biopsy composition. In conclusion, regardless of the type of soft tissue graft used, socket preservation with DBBG at sites presenting facial bone defects enabled implant placement without further guided bone regeneration, whether the sockets were sealed with FGG or CMX.

Received: March 2021; Accepted: May 2021.

Keywords: bone substitutes - dental materials - bone replacement - guided tissue regeneration.

\section{Impacto do enxerto de tecido mole na preservação de alvéolos comprometidos: um estudo piloto clínico controlado randomizado}

\begin{abstract}
RESUMO
O objetivo deste estudo piloto foi avaliar o impacto da associação de enxerto gengival livre (FGG) ou xenoenxerto de matriz de colágeno (CMX) ao enxerto ósseo bovino desproteinizado (DBBG) na preservação de alvéolos pós-extração com defeitos da parede óssea vestibular. Foram selecionados 16 pacientes que apresentavam dente superior com defeito ósseo vestibular e indicação de extração. Após o procedimento cirúrgico, todos os alvéolos pós-extração foram preenchidos com $D B B G$ e recobertos por membrana de colágeno. A parte cervical dos alvéolos foi então selada com FGG ou CMX. As análises clínicas e tomográficas foram realizadas no início do estudo e 4 meses
\end{abstract}

após o procedimento de enxerto. Os alvéolos pós-extração tratados com FGG apresentaram maiores valores para a largura da crista óssea do que os alvéolos tratados com CMX na avaliação de 4 meses. Não houve diferenças em relação à composição da biópsia. Em conclusão, independentemente do tipo de enxerto de tecido mole utilizado, a preservação dos alvéolos com DBBG em locais com defeitos ósseos faciais permitiu a colocação do implante sem regeneração óssea guiada.

Palavras-chave: substitutos ósseos - materiais dentários - substituição ósea - regeneração óssea guiada. 


\section{INTRODUCTION}

Despite the rapid evolution of dentistry in recent years, tooth loss is still a public health issue around the world ${ }^{1}$, and a considerable part of the population may still need rehabilitation with dental implants and prostheses to replace lost teeth. Unless sufficient bone is available, placing a dental implant in an adequate position for successful prosthetic rehabilitation may require guided bone regeneration (GBR) procedures ${ }^{2,3}$. Therefore, preservation of the ridge volume should be considered whenever a tooth is extracted.

After tooth extraction, the socket undergoes several biological events leading to bone formation in its internal portion, and bone loss, especially on the facial aspect ${ }^{4}$ of the socket. Ridge dimensions are reduced after extraction and it may not be possible to install a dental implant without GBR procedures, particularly in critical aesthetic areas. Several studies have demonstrated the uneventful bone-remodeling pattern in intact extraction sockets and reported a loss of approximately $50 \%$ of its original width $^{5-8}$, which represents an absolute loss of 2.6-4.6 $\mathrm{mm}^{9-12}$. In such situations, socket preservation with slow-resorbing osteoconductive biomaterials can reduce this loss to values of about $0.5-1.5 \mathrm{~mm}^{9,11,13,14}$. Teeth that are indicated for extraction normally present complications such as fracture, extensive decay, root resorption or bone loss ${ }^{1,15}$. The dynamics of bone remodeling is impaired when bone defect in the socket is present ${ }^{3}$. If one of the socket walls is damaged, more bone resorption can be expected after tooth extraction, even when socket preservation is performed. The osteoconductive properties of the biomaterial and its role in maintaining space is hindered in compromised sockets ${ }^{13,16}$.

While bone grafts such as deproteinized bovine bone graft (DBBG) must be placed within the remaining bone walls, a soft tissue graft can also be used to seal the socket surface ${ }^{3,17}$. Autologous free gingival graft, sub-epithelial connective tissue graft, or a soft tissue substitute can all be used as socket sealers to prevent contamination, outer migration of bone particles, and flap advancement and displacement of the mucogingival junction. Post-operative discomfort, bleeding, and increased surgery time are among the drawbacks encountered when autologous free gingival grafts are employed ${ }^{18,19}$.

The use soft tissue substitutes (STS) prevents morbidity at the harvesting site and enables the match of tissue texture and color ${ }^{20,21}$. The heterologous 3-dimensional collagen matrix is an STS that presents two layers: a compact layer that enables sutures and provides stability; and a spongy layer that increases blood absorption, clot organization and integration of the graft to the recipient site ${ }^{22}$. This kind of substitute is usually recommended in intact sockets, which restricts its use in clinical practice. In order to evaluate its performance in more challenging situations, the aim of this randomized controlled clinical pilot study was to evaluate the impact of the association of free gingival graft (FGG) or collagen-matrix xenograft (CMX) to deproteinized bovine bone graft (DBBG) on the preservation of post-extraction sockets with facial-wall defects. The null hypothesis tested in this study was that FGG and CMX present the same clinical, tomographic and histomorphometric outcomes.

\section{MATERIAL AND METHODS Study Design}

For this trial, 16 patients were selected who had a maxillary premolar, a canine, or an incisor with a facial bone defect and indicated to be extracted. The sample consisted of patients who sought care at the School of Dentistry of Araraquara (FOAr-UNESP). The study was approved by the Ethics Committee on Human Studies: 32432714.3.0000.5416. Clinical and tomographic examinations were performed on the region to be intervened in each patient. Patients were selected according to the following criteria:

- Inclusion criteria: good oral hygiene with a plaque index below $20 \%$; presence of teeth adjacent to the tooth to be extracted with harmonious gingival architecture; age 18-65 years; level of clinical insertion on the labial surface $>3 \mathrm{~mm}$.

- Exclusion criteria: history of periodontal surgical procedures in the region to be operated; systemic disorders that would make them ineligible for surgical procedures; presence of infection involving the gingival margin; history of radiotherapy treatment in the head and neck region; bruxism; individuals considered to be smokers; alcoholics; drug users; diabetics; pregnant; users of medications that might interfere with bone remodeling; and individuals affected by any pathology that could alter bone metabolism.

The surgical procedure was characterized by the removal of the compromised tooth under an atraumatic technique, which employs a periotome 
or residual root extractor in an attempt to preserve any remaining labial bone or adjacent bone plates. After extraction, each socket was thoroughly curetted, cleaned and inspected. All post-extraction sockets were filled with deproteinized bovine bone graft (DBBG) associated with 10\% collagen (approximately $0.5 \mathrm{~g}$ per post-extraction socket). Then patients were allocated to two groups according the type of STS used to cover the upper portions of the sockets: CMX -The sockets were covered with a collagen matrix xenograft (Mucograft Seal ${ }^{\circ}$, Geistlich Pharmaceutical, Wolhausen, Switzerland); FGG- The sockets were covered with an autologous free gingival graft. The area corresponding to the facial bone wall was covered with an extension of a resorbable collagen membrane (Bio-Gide $\AA$, Geistlich Pharmaceutical, Wolhausen, Switzerland). In all patients, the internal epithelium of the gingival margin was initially removed before insertion of the CMX or the FGG, which was fitted and sutured in the recipient site with a 5-0 resorbable thread.
At the end of the surgical procedure, each patient received a removable or adhesive provisional prosthesis, installed over the adjacent teeth for greater aesthetic comfort until the healing phase was completed. Patients were instructed on postoperative care and diet restrictions. For postoperative medications, patients were prescribed oral use of $500 \mathrm{mg}$ of amoxicillin every 8 hours for 7 days, and $200 \mathrm{mg}$ of Ibuprofen every 6 hours in case of pain. Sutures were removed seven days after the surgical procedure.

After 120 days, a new surgical procedure was performed to install a cone-Morse taper implant, (Drive $\mathrm{CM} \circledast$, Acqua surface, Neodent, Curitiba-Brazil) in adequate position for successful prosthetic rehabilitation. In 10 of the patients, 5 from each group, after the flap was elevated and the surgical guide was positioned, the bone edge was first slightly marked with the tip of the spear cutter, which had a median diameter of $2 \mathrm{~mm}$. Drilling for implant installation was initiated with a $2 \mathrm{~mm}$ diameter trephine bur, in order to obtain a biopsy of the bone tissue (5-7
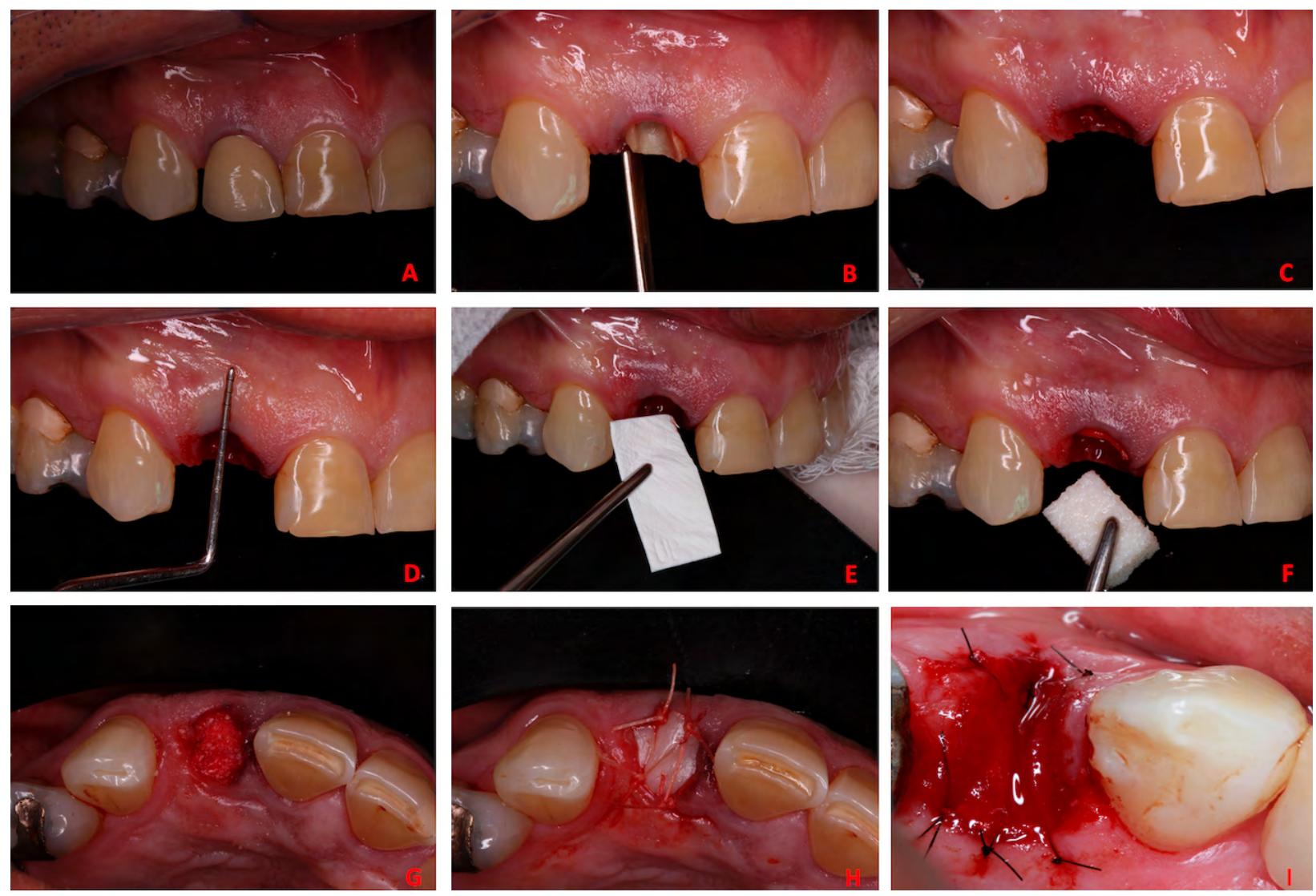

Fig. 1: Surgical procedure. A) The anterior upper tooth indicated for extraction (12); B) Removing the compromised tooth using an atraumatic technique; C) Clinical condition of the post-extraction socket; D) The diagnosis of the reduced labial bone; E) Insertion of the collagen membrane; F) Placement of the DBBG; G) The post-extraction socket filled with DBBG; H) Occlusion of the upper portion of the post-extraction socket with FGG; I) Occlusion of the upper portion of the post-extraction socket with CMX 
$\mathrm{mm}$ long). For all implants, the bone site was under-drilled in an attempt to increase primary stability values. Following the second surgical procedure, patients received the same provisional prosthesis that had initially been installed, or a new one if any color alteration, cracking or damage was detected. Two months later, the implants were exposed for the installation of a healing abutment and the patients were referred for completion of the restorative treatment. The images of the surgical procedures are provided in Fig.1.

\section{Clinical analysis}

Clinical data were recorded at the beginning of the study and 120 days after the grafting procedure, with 16 patients completing this analysis, of whom 7 were from the CMX group and 9 from the FGG (control) group. The height and thickness of keratinized gingiva, gingival margin level, and gingival biotype were measured with the aid of a PCP-UNC 15 millimeter-gauged probe (Millennium-Golgran, São Caetano do Sul, Brazil). The following clinical analyses were performed at baseline and at 120 days after the grafting procedure: height of keratinized gingiva, distance from the gingival margin to the facial (vestibular) crestal bone (GM-VCB) and the palatine crestal bone (GM-PCB); and distance from the distal and mesial papilla to the top of the ridge of the interproximal bone (GM-DIB and GM-MIB). Soft tissue thickness was measured with a caliper, $2 \mathrm{~mm}$ apical from the gingival margin. When present, any complications from the surgical procedures were recorded at this stage.

\section{Cone Beam Computed Tomography analysis}

Two patients from the FGG group were excluded from tomographic analysis because the final tomography could not be performed. Thus, 7 patients per group were included in this analysis. The patients underwent cone beam computed tomography for dental, bone and gingival evaluation of the surgical area at baseline and 120 days after the surgical procedure, with a Newtom QR-DVT scanner (QR-Verona, Verona, Italy). The following parameters were measured: distance from the top to the base of the facial (vestibular) bone (TB-V); distance from the top to the base of the palatine bone (TB-P); and width of the bone at $2.5 \mathrm{~mm}$ and $9 \mathrm{~mm}$ from the top of the bone ridge. All the measurements were performed with the software Osirix (Pixmeo, Geneva, Switzerland).

\section{Histological analysis and histomorphometric evaluation}

The harvested biopsies were decalcified in 7\% EDTA for 3 months and then processed to obtain histological sections, and stained with Masson's trichrome. The section was obtained from the central portion of the biopsies, and two sections of each biopsy were analyzed. The entire biopsies were photograph at $25 \mathrm{X}$ magnification with the aid of an optical microscope. Then, the images were analyzed to detect the composition of the newly formed tissues as a percentage of the total area of the biopsies (bone, biomaterial and soft tissue). The histological description of the biopsies assessed the quality of the new bone, the appearance of the bone substitute remnants, the interface between the bone substitutes particle and bone, and the inflammatory response.

\section{Statistical Analysis}

All the data generated by this study had normal distribution, confirmed by the Kolgomorov-Smirnov normality test; so parametric models were used for inferential data analysis ( $p>0.05)$. The comparison within each group between experimental times was performed using the paired t-test, while the comparison between groups within each experimental time was performed using the unpaired t-test. Graphpad Prism 6 software (San Diego, CA, USA) was used to perform the statistical analysis and all tests were applied at a significance level of $5 \%$.

\section{RESULTS}

\section{Computed Tomography Analysis}

Both treatments were found to promote an increase in TB-V values by the end of 4 months compared to baseline. Sites treated with FGG showed higher values in the $\mathrm{L}-2 \mathrm{~mm}$ and $\mathrm{L}-5 \mathrm{~mm}$ regions than the CMX sites at 4 months (Table 1).

\section{Clinical analysis}

The surgical procedure was observed to promote a decrease in the values of GM-VCB over the 4-month period in both groups. At 4 months, defects treated with CMX showed higher values of GM-PCB than those treated with FGG (Table 2).

\section{Histological analysis}

Histometric analysis of biopsy composition showed little presence of biomaterial, and strong presence of bone and soft tissue, with no difference between 
Table 1. Mean and standard deviation data on tomographic analysis in both evaluation times

\section{Parameters/Time}

\begin{tabular}{|c|c|}
\hline & FGG \\
\hline TB-V & $10.03 \pm 4.52$ \\
\hline TB-P & $16.53 \pm 4.56$ \\
\hline W-2mm & $8.17 \pm 0.87$ \\
\hline W-5mm & $9.41 \pm 1.65$ \\
\hline W-9mm & $10.10 \pm 2.50$ \\
\hline
\end{tabular}

\section{Baseline}

XCM

$8.85 \pm 3.77$

$15.13 \pm 3.52$

$7.45 \pm 1.25$

$8.06 \pm 1.34$

$9.18 \pm 1.55$
4 months

FGG

XCM

$15.60 \pm 2.05^{*}$

$17.12 \pm 0.93$

$6.21 \pm 1.42$

$7.25 \pm 1.14$

$8.86 \pm 1.21$

TB-V- Distance from the top to the base of the vestibular bone; TB-P-Distance from the top to the base of the palatine bone; W-Width. * $\mathrm{p}<0.05$; ${ }^{* *} \mathrm{p}<0.01$ - Higher values than at baseline - Paired t-test; $\otimes p<0.05$ - Higher values than the XCM at 4 months - Unpaired $t$-test.

Table 2. Mean and standard deviation data from the clinical analyses at baseline and 4 months.

Parameters/Time

GM-VCB
GM-PCB
GM-MIB
GM-DIB

GT

FGG
$5.66 \pm 0.81$
$3.33 \pm 1.03$
$3.33 \pm 0.81$
$3.33 \pm 0.81$
$2.41 \pm 0.49$

Baseline
4 months

\begin{tabular}{c|c} 
FGG & XCM \\
\hline $4.50 \pm 1.04 \#$ & $5.33 \pm 1.03 \# \#$ \\
\hline $3.33 \pm 1.03$ & $3.66 \pm 1.03^{*}$ \\
\hline $3.16 \pm 0.40$ & $3.83 \pm 0.75$ \\
\hline $3.00 \pm 0.00$ & $3.50 \pm 0.54$ \\
\hline $2.16 \pm 0.40$ & $2.25 \pm 0.41$
\end{tabular}

GM-VCB: Distance from gingival margin to the vestibular crestal bone; GM-PCB: Distance from gingival margin to the palatine crestal bone; GM-MIB Distance from gingival margin to the mesial interproximal bone; GM-DIB: Distance from gingival margin to the distal interproximal bone; GT-Gingival thickness. ${ }^{*} \mathrm{p}<0.05$ - Higher values than at baseline - Paired $\mathrm{t}$-test; $\# \mathrm{p}<0.05 ; \# \# \mathrm{p}<0.01$ - Lower values than at baseline - Paired t-test. $\llbracket p<0.01-$ Higher values than the FGG at baseline - Unpaired t-test.

groups. The grafted areas presented bone with high degree of maturation, organized in concentric lamellae, with bone formed in close contact with the remaining DBBG particles without major inflammatory findings (Fig. 2).

\section{Histomorphometic Evaluation}

The CMX group showed $34.08 \pm 5.12 \%$ of bone, $4.98 \pm 2.45 \%$ of remnants of biomaterial and 60.94 $\pm 8.14 \%$ of soft tissue. The FGG group showed $32.60 \pm 6.05 \%$ of bone, $7.93 \pm 4.31 \%$ of bioma-
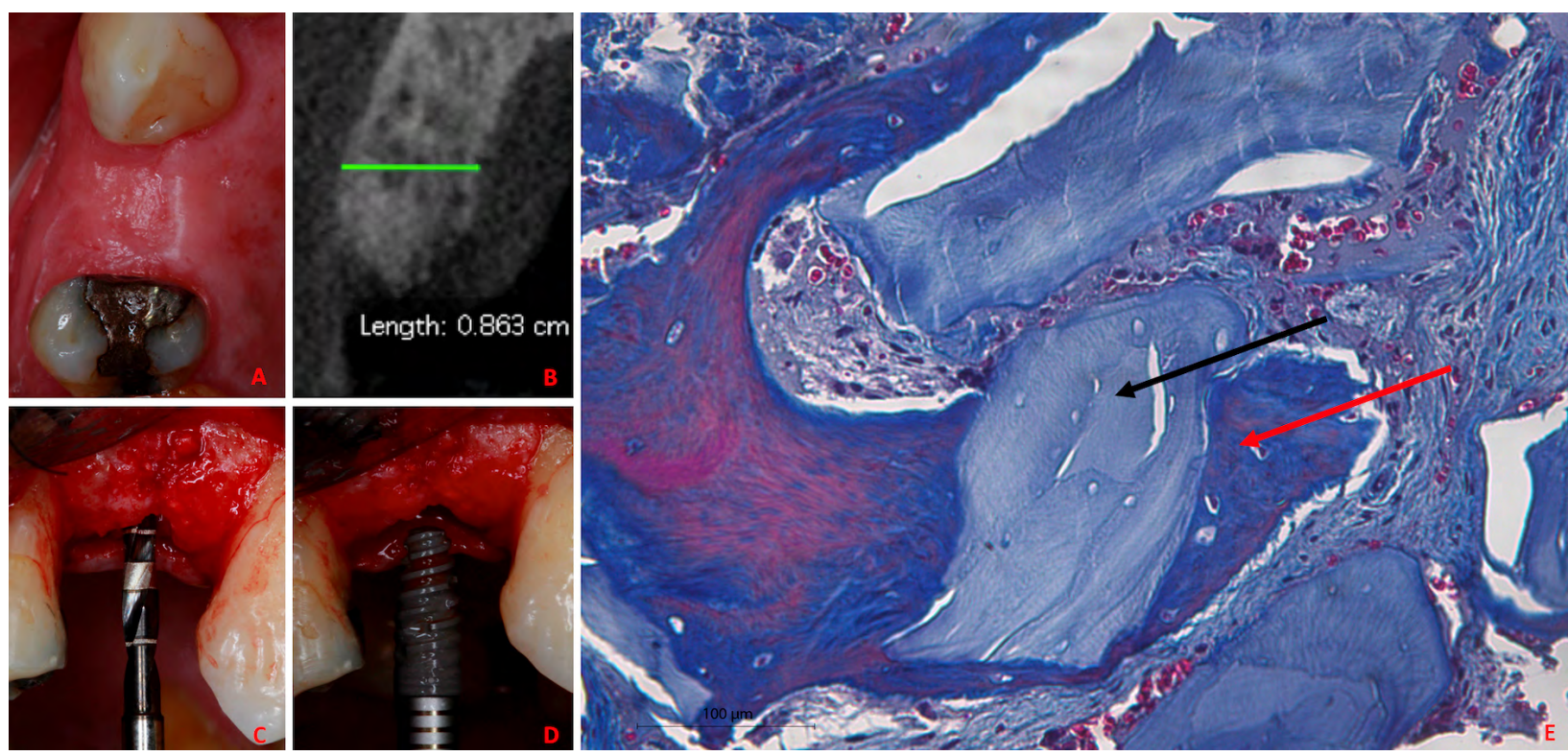

Fig. 2: Follow-up 4 months after the surgical procedure. A) Clinical condition of the soft tissues with adequate amount of keratinized tissues; B) CT images showing an adequate amount of bone tissue for implant placement; C) Drilling the bone for implant placement; D) Implant placement; E) Biopsy analysis showed presence of DBBG (Black Arrow) in close contact with the new bone (Red arrow) - (Masson Trichrome stain - 100x original magnification) 
terial and $59.57 \pm 7.83 \%$ of soft tissue. Figure 2 shows the clinical conditions and the appearance of the biopsies 4 months after the graft procedure in both groups.

\section{DISCUSSION}

The presence of large buccal defects associated with post-extraction sockets impairs immediate implant placement and requires reconstruction using the guided bone regeneration technique ${ }^{5}$. The use of STS has recently been indicated in these cases in order to improve the soft tissue conditions prior to implant placement ${ }^{16}$. This study showed that CMX may be an alternative for FGG, since socket preservation at sites with labial wall defects enabled successful placement of dental implants after four months of healing without further GBR. Thus, the null hypothesis was accepted. A previous prospective clinical study compared the outcomes of socket preservation with deproteinized bovine bone mineral containing $10 \%$ of porcine collagen associated with a saddle subepithelial connective tissue graft (SCTG) in intact and compromised sockets. The need for complimentary grafting during implant placement has been reported especially at sites presenting a labial bone defect ${ }^{16}$. It is important to understand that there is a greater biological challenge in compromised sockets, resulting in reduced ridge dimensions after healing even when socket preservation is performed.

In this study, there was no significant statistical difference for soft tissue thickness according to the soft tissue graft used. Since the graft was used only as a sealer in the occlusal portion of the socket, there was no increase in labial soft tissue volume. In a previous study, our group reported greater volume in patients who received SCTG than in patients who were treated with CMX or with no soft tissue graft ${ }^{3}$. This seems to have occurred because the study evaluated the impact of the soft tissue grafts in compromised sockets that received an immediate provisional implant, so the grafts were placed on a labial pouch. While the regeneration of the ridge architecture can be quite challenging by doing GBR only, the use of soft tissue grafts can compensate for the remaining defect and provide a thick, more resilient peri-implant mucosa ${ }^{3,16}$.

Treatment of sockets with DBBG containing $10 \%$ of porcine collagen has been extensively demonstrated in both animal ${ }^{23-25}$ and human studies ${ }^{3,26-28}$. Although most studies have reported outcomes in intact sockets, our greatest clinical challenges are sockets that present bone defects. Several techniques have been described for regenerating a missing facial wall but the results are limited to the vertical and horizontal extent of the bone defect ${ }^{29,30}$. Moreover, there seems to be a lack of consensus on whether or not a membrane should be used in association with bone grafts when sockets are treated for bone regeneration ${ }^{8,31,32}$. Nonetheless, our choice in this study was to use a collagen membrane to prevent migration of cells from the soft tissue and try to foster regeneration of the missing bone wall.

The socket undergoes several events after extraction, and most of the ridge reduction occurs in the first three months. However, remodeling of the ridge thickness continues throughout the patient's life. The thickness of the facial wall and the size of the defect can play a major role in the socket regeneration and long-term maintenance. In cases where there is a thick facial wall, less resorption can be expected after tooth extraction. In aesthetic areas, this wall is rarely thicker than $2 \mathrm{~mm}$, and is usually about $0.5 \mathrm{~mm}$ thick $^{33,34}$. Whenever there is a defect on the facial wall, both vertical and horizontal aspects must be assessed. Kan et $\mathrm{al}^{35}$ demonstrated greater soft tissue alterations in wider defects, while Pang et $\mathrm{al}^{34}$ showed that socket preservation presented a remarkable effect whenever the defects were greater than $5 \mathrm{~mm}$. In our study, there was a significant difference between groups regarding the facial bone vertical defect, where patients from the CMX group presented greater labial loss. This difference occurred most likely due to the small sample size and could have been influenced by the fact that patients who received CMX had a greater area to be regenerated and less bone support to aid in the new bone formation.

Considering this result, it could be argued that CMX outperformed the free gingival graft, but there is no evidence in such regard. In this type of technique, both soft tissues can be used to seal the socket and avoid the need to raise and advance a flap, while the DBBG would be responsible for the bone regeneration $^{20,31}$. This was shown in the histological analysis, as there was no significant statistical difference between groups. The use of soft tissue substitutes as socket sealers is technically less challenging, more reproducible and therefore more advantageous than most of the rather more elaborate grafting techniques available. 
Socket preservation in sites presenting a facial bone defect enabled placement of a dental implant with-

\section{DECLARATION OF CONFLICTING INTERESTS}

The authors declare no potential conflicts of interest regarding the research, authorship, and/or publication of this article

\section{FUNDING}

None

\section{REFERENCES}

1. Kassebaum NJ, Smith AGC, Bernabé E, Fleming TD et al. Global, Regional, and National Prevalence, Incidence, and Disability-Adjusted Life Years for Oral Conditions for 195 Countries, 1990-2015: A Systematic Analysis for the Global Burden of Diseases, Injuries, and Risk Factors. J Dent Res. 2017;96:380-387.

2. Chiapasco M, Casentini P. Horizontal bone-augmentation procedures in implant dentistry: prosthetically guided regeneration. Periodontol 2000. 2018; 77:213-240.

3. Frizzera F, de Freitas RM, Muñoz-Chávez OF, Cabral G et al. Impact of Soft Tissue Grafts to Reduce Peri-implant Alterations After Immediate Implant Placement and Provisionalization in Compromised Sockets. Int J Periodontics Restorative Dent. 2019; 39:381-389.

4. Araújo MG, Lindhe J. Dimensional ridge alterations following tooth extraction. An experimental study in the dog. J Clin Periodontol. 2005; 32:212-218.

5. Nevins M, Camelo M, De Paoli S, Friedland B et al. A study of the fate of the buccal wall of extraction sockets of teeth with prominent roots. Int J Periodontics Restorative Dent. 2006; 26:19-29.

6. Van der Weijden F, Dell'Acqua F, Slot DE. Alveolar bone dimensional changes of post-extraction sockets in humans: a systematic review. J Clin Periodontol. 2009; 36:10481058.

7. Tan WL, Wong TL, Wong MC, Lang NP. A systematic review of post-extractional alveolar hard and soft tissue dimensional changes in humans. Clin Oral Implants Res. 2012; 23 Suppl 5: 1-21.

8. Tan-Chu JH, Tuminelli FJ, Kurtz KS, Tarnow DP. Analysis of buccolingual dimensional changes of the extraction socket using the "ice cream cone" flapless grafting technique. Int J Periodontics Restorative Dent. 2014; 34:399-403.

9. Lekovic V, Kenney EB, Weinlaender M, Han T et al. A bone regenerative approach to alveolar ridge maintenance following tooth extraction. Report of 10 cases. J Periodontol. 1997; 68: 563-570.

10. Covani U, Cornelini R, Barone A. Bucco-lingual bone remodeling around implants placed into immediate extraction sockets: a case series. J Periodontol. 2003; 74: 268-273.

11. Iasella JM, Greenwell H, Miller RL, Hill M et al. Ridge preservation with freeze-dried bone allograft and a collagen membrane compared to extraction alone for implant site development: a clinical and histologic study in humans. J Periodontol. 2003; 74:990-999.

12. Hämmerle $\mathrm{CH}$, Araújo MG, Simion M; Osteology Consen out further GBR, regardless of the type of soft tissue graft used to seal the socket.

\section{CORRESPONDENCE}

Elcio Marcantonio Jr

Humaitá St., 1680. Zip-Code 14801-130, Araraquara, SP. Brasil elciojr@foar.unesp.br

sus Group 2011. Evidence-based knowledge on the biology and treatment of extraction sockets. Clin Oral Implants Res. 2012; 23: 80-82.

13. Kan JY, Rungcharassaeng K, Morimoto T, Lozada J. Facial gingival tissue stability after connective tissue graft with single immediate tooth replacement in the esthetic zone: consecutive case report. J Oral Maxillofac Surg. 2009; 67:40-48.

14. Roe P, Kan JY, Rungcharassaeng K, Caruso JM et al. Horizontal and vertical dimensional changes of peri-implant facial bone following immediate placement and provisionalization of maxillary anterior single implants: a 1-year cone beam computed tomography study. Int J Oral Maxillofac Implants. 2012; 27: 393-400.

15. Clark D, Levin L. In the dental implant era, why do we still bother saving teeth? Dent Traumatol. 2019; 35:368-375.

16. Seyssens L, Eghbali A, Christiaens V, De Bruyckere T et al. A one-year prospective study on alveolar ridge preservation using collagen-enriched deproteinized bovine bone mineral and saddle connective tissue graft: A cone beam computed tomography analysis. Clin Implant Dent Relat Res. 2019; 21:853-886.

17. Thalmair T, Fickl S, Schneider D, Hinze M, Wachtel H. Dimensional alterations of extraction sites after different alveolar ridge preservation techniques - a volumetric study. J Clin Periodontol. 2013; 40:721-727.

18. Oates TW, Robinson M, Gunsolley JC. Surgical therapies for the treatment of gingival recession. A systematic review. Ann Periodontol. 2003; 8:303-320.

19. Chambrone L, Sukekava F, Araújo MG, Pustiglioni FE et al. Root-coverage procedures for the treatment of localized recession-type defects: a Cochrane systematic review. J Periodontol. 2010; 81:452-478.

20. McGuire MK, Scheyer ET. Randomized, controlled clinical trial to evaluate a xenogeneic collagen matrix as an alternative to free gingival grafting for oral soft tissue augmentation. J Periodontol. 2014; 85:1333-1341.

21. Jung RE, Ioannidis A, Hämmerle CHF, Thoma DS. Alveolar ridge preservation in the esthetic zone. Periodontol 2000. 2018; 77:165-175.

22. Sanz M, Lorenzo R, Aranda JJ, Martin C et al. Clinical evaluation of a new collagen matrix (Mucograft prototype) to enhance the width of keratinized tissue in patients with fixed prosthetic restorations: a randomized prospective clinical trial. J Clin Periodontol. 2009; 36:868-876.

23. Araújo M, Linder E, Wennström J, Lindhe J. The influence 
of Bio-Oss Collagen on healing of an extraction socket: an experimental study in the dog. Int J Periodontics Restorative Dent. 2008; 28:123-135.

24. Araújo MG, Lindhe J. Ridge preservation with the use of Bio-Oss collagen: A 6-month study in the dog. Clin Oral Implants Res. 2009; 20:433-440.

25. Araújo MG, Linder E, Lindhe J. Bio-Oss collagen in the buccal gap at immediate implants: a 6-month study in the dog. Clin Oral Implants Res. 2011; 22:1-8.

26. Araújo MG, da Silva JCC, de Mendonça AF, Lindhe J. Ridge alterations following grafting of fresh extraction sockets in man. A randomized clinical trial. Clin Oral Implants Res. 2015; 26:407-412.

27. Maiorana C, Poli PP, Deflorian M, Testori T et al. Alveolar socket preservation with demineralised bovine bone mineral and a collagen matrix. J Periodontal Implant Sci. 2017; 47:194-210.

28. Troiano G, Zhurakivska K, Lo Muzio L, Laino L et al. Combination of bone graft and resorbable membrane for alveolar ridge preservation: A systematic review, meta-analysis, and trial sequential analysis. J Periodontol. 2018; 89:46-57.

29. Elian N, Cho SC, Froum S, Smith RB et al. A simplified socket classification and repair technique. Pract Proced Aesthet Dent. 2007; 19:99-104

30. Min S, Liu Y, Tang J, Xie Y et al. Alveolar ridge dimensional changes following ridge preservation procedure with novel devices: Part 1--CBCT linear analysis in non-human primate model. Clin Oral Implants Res. 2016; 27:97-105.

31. Huynh-Ba G, Pjetursson BE, Sanz M, Cecchinato D et al. Analysis of the socket bone wall dimensions in the upper maxilla in relation to immediate implant placement. Clin Oral Implants Res. 2010; 21:37-42.

32. You DJ, Yoon HJ. Bone Regeneration with Bilayer Bone Augmentation Technique for the Treatment of Dehiscence-Type Defects Around Implants: A Preliminary Study in Dogs. Int J Oral Maxillofac Implants. 2016; 31:318-323.

33. Sanz M, Cecchinato D, Ferrus J, Pjetursson EB et al. A prospective, randomized-controlled clinical trial to evaluate bone preservation using implants with different geometry placed into extraction sockets in the maxilla. Clin Oral Implants Res. 2010; 21:13-21.

34. Pang KM, Um IW, Kim YK, Woo JM et al. Autogenous demineralized dentin matrix from extracted tooth for the augmentation of alveolar bone defect: a prospective randomized clinical trial in comparison with anorganic bovine bone. Clin Oral Implants Res. 2017; 28:809-815.

35. Kan JY, Rungcharassaeng K, Sclar A, Lozada JL. Effects of the facial osseous defect morphology on gingival dynamics after immediate tooth replacement and guided bone regeneration: 1-year results. J Oral Maxillofac Surg. 2007; 65:1319. 